CALIFORNIA STUDIES IN FOOD AND CULTURE

Darra Goldstein, Editor 


\title{
WEIGHING IN
}

OBESITY, FOOD JUSTICE,

AND THE LIMITS OF CAPITALISM

\author{
Julie Guthman
}

\section{甲}

UNIVERSITY OF CALIFORNIA PRESS

Berkeley Los Angeles London 
University of California Press, one of the most distinguished university presses in the United States, enriches lives around the world by advancing scholarship in the humanities, social sciences, and natural sciences. Its activities are supported by the UC Press Foundation and by philanthropic contributions from individuals and institutions. For more information, visit www.ucpress.edu.

University of California Press

Berkeley and Los Angeles, California

University of California Press, Ltd.

London, England

(C) 20 I I by Julie Guthman

Library of Congress Cataloging-in-Publication Data

Guthman, Julie.

Weighing in : obesity, food justice, and the limits of capitalism / Julie Guthman.

p. $\mathrm{cm}$.

Includes bibliographical references and index. ISBN 978-0-520-26624-7 (cloth : alk. paper) ISBN 978-0-520-26625-4 (pbk. : alk. paper)

I. Obesity, Social aspects. I. Title.

RA645. ${ }_{23} \mathrm{G} 88$ 20II

$362.196^{\prime} 398-\mathrm{dc2} 2$

2011003848

Manufactured in the United States of America
$\begin{array}{llllllllll}20 & \text { I9 } & \text { I8 } & \text { I7 } & \text { I6 } & \text { I5 } & \text { I4 } & \text { I3 } & \text { I2 } & \text { II }\end{array}$
$\begin{array}{llllllllll}\text { IO } & 9 & 8 & 7 & 6 & 5 & 4 & 3 & 2 & \text { I }\end{array}$

This book is printed on Cascades Enviro I00, a Ioo\% post consumer waste, recycled, de-inked fiber. FSC recycled certified and processed chlorine free. It is acid free, Ecologo certified, and manufactured by BioGas energy. 
To Mom, for Sierra 
